\title{
Flávio Munhoz Sofiati, Juventude Católica: o novo discurso da Teologia da Libertação
}

São Carlos, SP, Brasil, Editora da Universidade Federal de Sao Carlos, 2012, 175 p.

\section{Rodolfo de Roux}

\section{(2) OpenEdition}

\section{Journals}

Edición electrónica

URL: http://journals.openedition.org/assr/25621

DOI: $10.4000 /$ assr.25621

ISSN: $1777-5825$

\section{Editor}

Éditions de l'EHESS

\section{Edición impresa}

Fecha de publicación: 30 diciembre 2013

Paginación: 289

ISSN: 0335-5985

\section{Referencia electrónica}

Rodolfo de Roux, «Flávio Munhoz Sofiati, Juventude Católica: o novo discurso da Teologia da Libertação », Archives de sciences sociales des religions [En línea], 164 | 2013, Publicado el 14 marzo 2014, consultado el 21 septiembre 2020. URL : http://journals.openedition.org/assr/25621 ; DOI : https://doi.org/10.4000/assr.25621

Este documento fue generado automáticamente el 21 septiembre 2020.

(c) Archives de sciences sociales des religions 


\section{Flávio Munhoz Sofiati, Juventude Católica: o novo discurso da Teologia da Libertação}

São Carlos, SP, Brasil, Editora da Universidade Federal de Sao Carlos, 2012, 175 p.

Rodolfo de Roux

\section{REFERENCIA}

Flávio Munhoz Sofiati, Juventude Católica: o novo discurso da Teologia da Libertação, São Carlos, SP, Brasil, Editora da Universidade Federal de Sao Carlos, 2012, 175 p. 
El autor - profesor adjunto de sociología en la Universidad Federal de Goiás analiza desde una perspectiva sociohistórica el método de formación utilizado por la Iglesia católica del Brasil en su Pastoral Juvenil y la transformación de las opciones políticas de dicha pastoral en las décadas 1970-1980 y 1990-2000.

La primera parte, Gênese do Cristianismo da Libertação (p. 27-72), analiza el hecho de que la actual Pastoral da Juventude do Brasil (PJB) es heredera de las corrientes de Izquierda Católica que surgieron en las décadas de 1950 y 1960. Se subraya particularmente el influjo que tuvieron la JUC (Juventud Universitaria Católica) y la JOC (Juventud Obrera Católica) sobre la PJB.

\section{La segunda parte, 0 método da formação da}

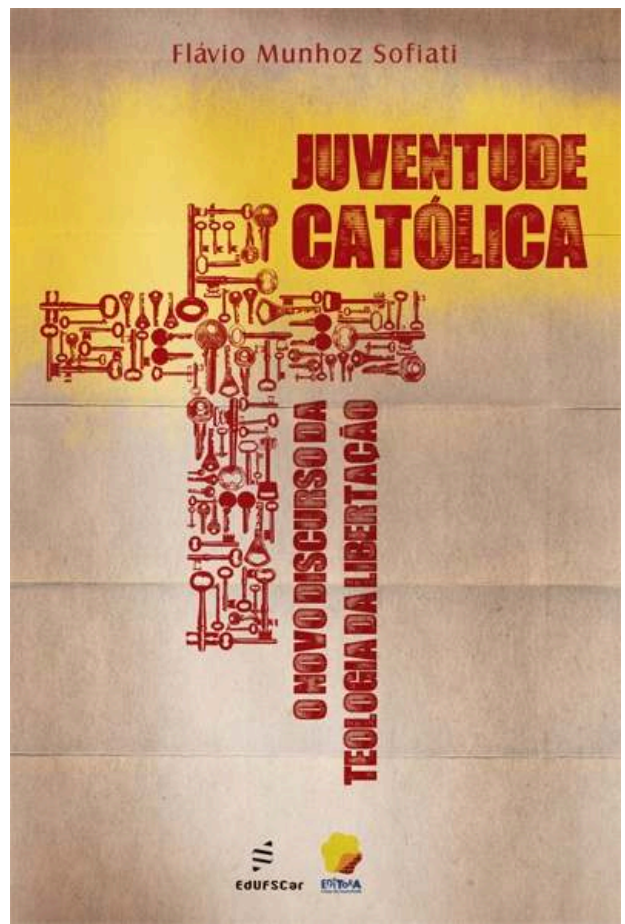
PJB (p. 73-98), señala la consolidación de la PJB a escala nacional en la década de 1980. Consolidación que fue acompañada de un desarrollo de su método de formación que se procura analizar, lo mismo que se procura comprender la importancia e influencia de la PJB en el Brasil. que llevaron a reevaluar el método de trabajo de la PJB. Entre 1990 y 1995 se dio una fuerte crisis en la Pastoral Juvenil como consecuencia de las transformaciones en la sociedad brasileña y del enfrentamiento de diferentes visiones respecto a la orientación de las pastorales juveniles específicas. Para superar esta crisis se realizó en 1995 una Asamblea Nacional de la que surgió la Pastoral da Juventude do Brasil (PJB) que engloba las diferentes pastorales juveniles de la Iglesia católica: Pastoral da Juventude (PJ), Pastoral da Juventude do Meio Popular (PJMP), Pastoral da Juventude Rural (PJR), y Pastoral da Juventude Estudiantil (PJE). Esta Asamblea de 1995 definió un plan nacional de evangelización de los jóvenes, conocido como Plano Trienal. Dicho Plan, que Sofiati analiza al final de su trabajo, traza el camino que la PJB ha recorrido en los últimos años.

l subtítulo del libro puede llamar a engaño pues no se trata de un trabajo sobre la Teología de la Liberación. Pero se justifica en cuanto que Sofiati hace énfasis en la articulación entre la PJB y la Teología de la liberación (TL), y postula que la crisis del proyecto de la TL trajo como consecuencia la crisis del modelo de pastoral juvenil que se había gestado en la década de 1970. Si en la década de 1980 la Pastoral Juvenil privilegió el compromiso político-religioso, Sofiati analiza porqué en la segunda mitad de la década de 1990 la PJB pasó a hacer énfasis en la dimensión espiritual de la formación de los jóvenes y en su formación bíblica y litúrgica. El subtítulo también se justifica por las páginas dedicadas a $O$ novo significado da « opção pelos pobres » na Teologia da Libertação (p. 115-130). En ellas, Sofiati compara algunas afirmaciones del chileno Pablo Richard y del brasileño Leonardo Boff hechas en los años 1970-1990 y luégo en los años 1990-2000. El autor concluye que la ampliación de la noción de «opción 
preferencial por los pobres » para incluir problemáticas ecológicas, étnicas y feministas ha llevado en la TL a un distanciamiento del método marxista de interpretación de la realidad.

6 En un escrito breve pero sustancioso que muestra un sólido bagaje teórico y que se apoya en documentos de la Iglesia católica brasileña, Sofiati ha sabido aprovechar su experiencia como ex-militante de la PJB para hacer un análisis académico y no apologético de la misma. 